\title{
S5ynthesis
}

International Scientific Conference of IT and Business-Related Research

\section{VIŠEKRITERIJUMSKA ANALIZA UPOTREBE INTERNETA U NASTAVI RAČUNOVODSTVA NA OSNOVNIM AKADEMSKIM STUDIJAMA}

\section{MULTI-CRITERIA ANALYSIS OF THE INTERNET USE IN TEACHING ACCOUNTING AT THE UNDERGRADUATE LEVEL}

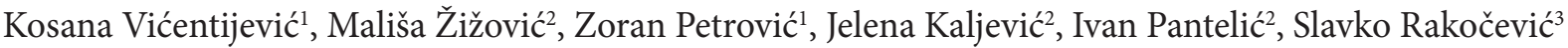 \\ ${ }^{1}$ Univerzitet Singidunum, Danijelova 32, Beograd, Srbija \\ ${ }^{2}$ Poslovni fakultet Valjevo, Železnička 5, Valjevo, Srbija \\ ${ }^{3}$ Univerzitet Mediteran, Vaka Đurovića bb, Podgorica, Crna Gora
}

\begin{abstract}
Apstrakt:
Tema rada je višekriterijumska analiza za potrebe izbora najbolje alternative za korišćenje Interneta u nastavi računovodstva na osnovnim akademskim studijama. Cilj rada jeste da se kroz višekriterijumsku analizu utvrdi optimalno učešće Interneta u nastavi računovodstva. Upotreba Interneta u izučavanju računovodstva ne može zameniti predavača i klasični način učenja računovodstva, ali je veoma poželjna. Naime, upotreba Interneta u nastavi računovodstva podstiče studente na veće angažovanje, utiče da nastavni proces bude zanimljiviji i studentima i predavačima, i omogućava studentima da prate važeću regulativu i budu spremni za rad u oblasti računovodstva. Sadržaj rada i zaključci koji iz njega proizilaze imaju za cilj da podstaknu veću primenu Interneta u izučavanju računovodstva na osnovnim akademskim studijama.
\end{abstract}

\section{Ključne reči:}

računovodstvo, Internet, višekriterijumska analiza, veb-aplikacije.

\section{UVOD}

Nastava iz predmeta Računovodstvo na osnovnim akademskim studijama na osnovu didaktičkih istraživanja može se sprovoditi na klasičan (tradicionalan) način i savremen način (upotrebom Interneta) kao i kombinacijom ovih metoda. Izučavanje računovodstva na osnovnim akademskim studijama ima za cilj da osposobi studente da pored osnovnih računovodstvenih tehnika, savladaju važeću računovodstvenu regulativu, elektronsku komunikaciju sa: Agencijom za privredne registre, Poreskom upravom i Centralnim registrom obveznika socijalnog osiguranja Republike Srbije. Pohađanje nastavnih aktivnosti na fakultetu iz predmeta Računovodstvo podrazumeva da predavači i studenti budu računarski pismeni. Potrebno je da na fakultetu postoje učionice sa personalnim računarima povezanim na Internet da bi mogli da nauče računovodstvenu elektronsku komunikaciju sa državnim organima.

Klasični način izučavanja računovodstva ne zahteva elektronsku opremljenost učionica, ali zahteva da nastavnik u prezentaciji uputstava i načina elektronske komunikacije sa državnim organima ima jedan računar povezan na Internet da bi prikazao studentima način obavljanja računovodstenih poslova. Studenti koji pohađaju nastavu računovodstva na klasičan način treba da budu upoznati sa elektronskim poslovanjem i upotrebom Interneta u savremenom računovodstvenom okruženju. Ovo podrazumeva da studenti i na klasičnim časovima računovodstva moraju proći kroz računarsku laboratoriju zbog savla-

\section{Abstract:}

The paper discusses the multi-criteria analysis for the purpose of choosing the best alternatives for use of the Internet in teaching accounting at undergraduate level of studies. The aim of the paper is to review the multiple criteria analysis and determine the optimal participation of the Internet in teaching accounting.

The use of the Internet in the study of accounting can not replace lecturers and the traditional teaching methods in the given field, but is highly desirable. The use of the Internet in teaching accounting encourages students' engagement, makes the teaching process more interesting for both students and lecturers, and enables students to keep pace with to the valid regulations and be more prepared to work in the area of accounting.

The content of the paper and its conclusions should trigger greater usage of the Internet in the study of accounting within undergraduate academic studies.

\section{Key words:}

accounting, Internet, multi-criteria analysis, Web application.

davanja navednog. Studenti na časovima treba da nauče koje informacije pruža određeni veb-sajt iz oblasti računovodstva i revizije kao što su sajtovi: Ministarstva finansija Republike Srbije, Narodne skupštine Republike Srbije, Državne revizorske institucije, Komore ovlašćenih revizora i drugih srodih institucija.

Izučavanje Računovodstva putem Interneta ne zahteva prethodna znanja iz drugih predmeta, osim osnovne digitalne pismenosti studenta. Od studenta se zahteva da bude osposobljen za komunikaciju sa navedenim institucijama, da komunicira i elektronski prati saopštenja sledećih institucija: Komisije za hartije od vrednosti , Beogradske berze, Produktne berze u Novom Sadu, Upave za sprečavanje pranja novca, Uprave za javne nabavke, Narodne banke Republike Srbije i drugih institucija umreženih u računovodstvenom poslovanju.

\section{MREŽNA METODA VIŠEKRITERIJUMSKOG ODLUČIVANJA}

Tokom poslednjih decenija razvijen je veliki broj metoda i tehnika višekriterijumske analize. U kombinaciji sa upotrebom modernih računara, većina ovih metoda ima dobru softversku podršku. U ovom radu koristimo osnovne pojmove, oznake i rezultate u vezi sa Mrežnim metodom višekriterijumskog odlučivanja za prikazivanje alternativa, kriterijuma i ocenjivanje primene Interneta u nastavi računovodstva na osnovnim akademskim studijama. 
Za pregled dostupnih metoda za rešavanje problema višekriterijumskog odlučivanja upućujemo na monografije (Nikolić \& Borović, 1996; Radojičić \& Žižović, 1998; Hwang \& Yoon, 1981; Triantaphyllou 2000; Figueira et al., 2005).

Koristeći Mrežni metod višekriterijumskog odlučivanja u našem radu definisani su alternative i kriterijumi za izvođenje nastave na predmetu Računovodstvo na osnovnim akademskim studijama.

Na fakultetima postoje razne mogućnosti za organizaciju i izvođenje nastave računovodstva. Ovde ćemo posmatrati neke od mogućih alternativa realizacije nastavnog procesa časova Računovodstva, koje su prikazane u Tabeli 1 .

\begin{tabular}{|c|l|}
\hline \multicolumn{2}{|c|}{ Alternative } \\
\hline A1 & $\begin{array}{l}\text { Tradicionalan način nastave Računovodstva. Na času pre- } \\
\text { davač izlaže tematske celine, a studenti prate predavanje. }\end{array}$ \\
\hline A2 & $\begin{array}{l}\text { Tradicionalan način nastave Računovodstva, podržan uz } \\
\text { Internet učenje. Predavač izlaže tematske celine uz prika- } \\
\text { zivanje Internet izvora i načina e-komunikacije i poslavanja } \\
\text { za tematsku oblast predavanja. Studenti prate predavanje } \\
\text { bez aktivnog učešća. }\end{array}$ \\
\hline A3 & $\begin{array}{l}\text { Studenti za nastavni predmet Računovodstvo dobijaju pisa- } \\
\text { na uputstva, snimljena predavanja, testove na Internetu za } \\
\text { proveru i vežbu stečenih znanja, praktično rade sa različitim } \\
\text { Internet tehnologijama. }\end{array}$ \\
\hline A4 & $\begin{array}{l}\text { Kombinovati treću varijantu i Internet učenje. Student za } \\
\text { svaku dilemu može koristiti e-mail radi objašnjenja i za } \\
\text { konsultacije sa profesorom. Interaktivne simulacije, e-mail, } \\
\text { animacije, student dobija za učenje i može da uči na fakul- } \\
\text { tetu, od kuće, sa posla. }\end{array}$ \\
\hline
\end{tabular}

Tabela 1. Alterantive primene Interneta u nastavi Računovodstva

Dati skup alternativa ocenićemo na osnovu četiri kriterijuma koji su prikazani u Tabeli 2 .

\section{Kriterijumi}

C1 Brzina razumevanja računovodstva i računovodstvenih akma računovodstvene profesije.

\begin{tabular}{|c|l|}
\hline C2 & $\begin{array}{l}\text { ma računovodstvene profesije. } \\
\text { tima za učenje. Učenje na klasični način sa pisanim materi- } \\
\text { jalima uz pasivno slušanje studenta sa vođenjem sopstvenih } \\
\text { beleški ili interaktivno putem Internet tehnologija. }\end{array}$ \\
\hline C3 & $\begin{array}{l}\text { Troškovi fakulteta za realizaciju nastavnog procesa predme- } \\
\text { ta Računovodstvo. }\end{array}$ \\
\hline C4 & $\begin{array}{l}\text { Postojanje tehničkih mogućnosti na Fakultetu za realizaciju } \\
\text { Internet nastave na časovima Računovodstva, ali i u studen- } \\
\text { tovom okruženju za učenje. }\end{array}$ \\
\hline C5 & $\begin{array}{l}\text { Usvojenost aktuelnih znanja i veština za računovodstvene } \\
\text { poslove i uvežbanost ovih veština. }\end{array}$ \\
\hline C6 & $\begin{array}{l}\text { Osposobljenost za aktivno uključivanje u radne aktivnosti } \\
\text { na računovodsvenim poslovima u privrednim subjektima. }\end{array}$ \\
\hline
\end{tabular}

Tabela 2. Kriterijumi savladavanja Računovodstva primenom Interneta u nastavi

Pretpostavka je da su svi kriterijumi maksimizirajućeg tipa (dovedeni su na tu varijantu) i da su ocene od 1 do 10 (sa tim što je 10 najbolje a 1 najslabije). Jasno je da je moguće postaviti i mnoge druge kriterijume kada je reč o izboru načina realizacije Internet nastave računovodstva, ali smatramo da će i ovi kriterijumi zadovoljiti potrebe izbora u najvećem broju slučajeva.
Kao kriterijumi bi mogli da budu i: sposobnost kandidata sa prosečnom ocenom da vodi računovodstvo malog privrednog društva, sposobnost kandidata koji je završio kurs da uspešno obavlja specijalizovane računovodstvene poslove (kao što je izrada biznis plana, mikro, malog ili srednjeg privrednog društva), sposobnost kandidata koji je ovladao Internet veštine na nastavi računovodstva da elektronski komunicira sa računovodstvenim okruženjem i uspešno izvršava poslove: elektronskog popunjavanja i slanja finansijskih izveštaja Agenciji za privredne registre, obračuna poreza i doprinosa i njihovog elektronkog slanja Poreskoj upravi Repulike Srbije, elektronskog plaćanja.

Višekriterijumsko rangiranje u Tabeli 3 je urađeno Mrežnom metodom za višekriterijumsko ocenjivanje prema proceduri datoj u radu Žižović et al. (2014).

Za potrebe ovog rada eksperti za računovodstvo koji predaju na fakultetima, koji direktno učestvuju u realizacije nastavnih aktivnosti su višekriterijumski ocenjivali primenu Interneta u nastavi računovodstva na akademskim studijama.

Tradicionalna nastava računovodstva ne može da zadovolji potrebe studenata za usvajanjem aktuelnih znanja i veština iz Računovodstva.

Savremeno okruženje zahteva od pojedinca koji je aktivan u računovodstvu, da individualno prati važeću regulativu, da je primenjuje i pretvara u upotrebljiva znanja.

Studenti na tradicionalnim časovima nisu dovoljno motivisani za usvajanje znanja i veština. Motivisanost studenata za izučavanje računovodstva je glavni faktor za modernizaciju i primenu Interneta u nastavi.

U tradicionalnoj nastavi računovodstva studenti su pasivni učesnici na času, njihova aktivnost je usmerena na praćenje izlaganja predavača bez mogućnosti da individulano pronalazi i uočava objektivna znanja i veštine, jer nemaju aktivnu ulogu u izvršavanju potencijalnih računovodstvenih poslova, za koje treba da ih osposobi nastava na fakultetu.

Primena Internet tehnologija u nastavi računovodstva zahteva od predavača i studenata aktivno učešće uz upotrebu računara. Saveremeni nastavni proces učenja računovodstva podrazumeva upotrebu računara sa Internetom, multimedije, ekspertni sistem, nastavne baze znanja inteligntne tutorske sisteme i druge savremene oblike elektronskog učenja.

\begin{tabular}{|c|c|c|c|c|c|c|}
\hline \multicolumn{7}{|c|}{ Ocene } \\
\hline Alternative & \multicolumn{7}{|c|}{ Kriterijumi } \\
\hline & C1 & C2 & C3 & C4 & C5 & C6 \\
\hline A1 & 10 & 8 & 10 & 9 & 5 & 5 \\
\hline A2 & 10 & 9 & 9 & 8 & 6 & 7 \\
\hline A3 & 8 & 9 & 8 & 8 & 8 & 8 \\
\hline A4 & 9 & 10 & 7 & 7 & 9 & 9 \\
\hline
\end{tabular}

Tabela 3. Ocene alternativa i kriterijuma u primeni Interneta $\mathrm{u}$ nastavi Računovodstva

$$
\mathrm{A} 4 \rightarrow \mathrm{A} 3 \rightarrow \mathrm{A} 2 \rightarrow \mathrm{A} 1
$$

Koristeći ovu metodu u našem radu se dobija da je alternativa A4 najbolja za skoro sve vrednosti težinskih koeficijenata, a pogotovu kada najveću vrednost težinskih koeficijenata dodelimo prvom i drugom kriterijumu.

Ocene u Tabeli 3 su date na osnovu mišljenja eksperata (profesora koji predaju predmet Računovodstvo na osnovnim akademskim studijama i računovodstvenih stručnjaka velikih privrednih društava iz Republike Srbije). 
Svi ovi eksperti računovodstva se slažu da je najjeftinija nastava Računovodstva po alternativi A1, pa potom po A2, A3 i A4 redom.

Ilustracije radi daćemo kako su formirane ocene za kriterijume C3 i C5.

Ovde je data ocena $10 \mathrm{za}$ "najbolju" alternativu po ovom kriterijumu C3 a ostale su za po 1 redom manje, zato što i nije moguće jeftinije organizovati nastavu. Slično po kriterijumu C5 svi eksperti se slažu da je najpovoljnija alternativa A4 pa onda redom A3 pa A2 i na kraju A1. Ovde je za A4 dato 9 a potom je izvršeno smanjenje za po 1 (pretpostavlja se da se može dati i još povoljnija alternativa po ovom kriterijumu kojoj bi se moglo dati 10).

$\mathrm{Na}$ osnovu sprovedene metode višekriterijumskog odlučivanja i iznetih zaključaka proizilazi potreba za primenom Interneta u izučavanju računovodstva na osnovnim akademskim studijama.

\section{REZIME}

Mrežna metoda višekriterijumskog odlučivanja se koristi kod postojanja velikog broja međusobno suprostavljenih kriterijuma koje treba uzeti u obzir prilikom donošenja odluke. Savremeni oblik obrazovanja podrazumeva donošenje odluka uzimajući u obzir veliki broj raznovrsnih kriterijuma. Zbog toga se metoda mrežnog odlučivanja nameće kao pogodan instrument za odlučivanje. Sem toga realnost u kojoj se donose složene odluke, uslovila je korišćenje metode višekriterijumskog odlučivanja u našem radu.

U radu je prezentovana primena mrežnog modela višekriterijumskog odlučivanja na empirijskim podacima za nastavni predmet Računovodstvo na osnovnim akademskim studijama.

Rezultat mrežne metode višekriterijumskog odlučivanja u našem radu ima za ocene $\mathrm{A} 4 \rightarrow \mathrm{A} 3 \rightarrow \mathrm{A} 2 \rightarrow \mathrm{A} 1$. Modelom je dokazano da je najbolje rešenje alternativa A4.

Višekriterijumska analiza je u radu pri izboru upotrebe Interneta u nastavi računovodstva ponudila rešenje na realnim podacima eksperata računovodstva. Model pruža brojne mogućnosti i alternative se mogu porediti po jednom kriterijumu ili po nekoliko kriterijuma u zavisnosti od preferencija donosioca odluka. Fakulteti mogu koristiti opisani model u svrhu poređenja sa drugim visokoškolskim institucijama, kao i u svrhu uočavanja sopstvenih slabosti koje treba unaprediti u svrhu kvalitetnije nastave računovodstva.

\section{LITERATURA}

Figueira, J., Greco, S., \& Ehrgott, M. (2005). Multiple criteria decision analysis: State of the art surveys. New York: Springer.

Hwang, C.L., \& Yoon, K. (1981). Multiple attribute decision making: Methods and applications: a state-of-the-art survey. Berlin: Springer-Verlag.

Kaljević, J., Pantelić, I., Milovanović, S., Petrović, Z., Vićentijević,K. (2013). Primena softverske simulacije u nastavi računovodstva. Sedmi međunarodni simpozijum Tehnologija, informatika i obrazovanje, Banja Luka, Sep, 2013. Banja Luka: Filozofski fakultet.

Nikolić, S., \& Borović, S. (1996). Višekriterijumska optimizacija, metode, primena u logistici, softver. Beograd: Centar vojnih škola Vojske Jugoslavije.

Pantelić, I., Kaljević, J., Milovanović, S., \& Vićentijević, K. (2013). Uticaj primene softverskog alata u nastavi računovodstva. IV Naučni skup Mreža 2013. maj 2013 (str. 79-84). Valjevo: Poslovni fakultet Valjevo Univerzitet Singidunum, Srbija.

Radojičić, M., \& Žižović. M. (1998). Applications of methods of multicriteria analysis in bussines decision-making. Čačak: Technical faculty in Čačak.

Triantaphyllou, E. (2000). Multi-criteria decision making methods: A comparative study. Dordrecht: Kluwer Academic Publishers.

Žižović, M., Kaljević, J., Pantelić, I., \& Vićentijević, K. (2014). Multicriteria Approach to Organization of Teaching Accounting. International Scientific Conference: UNITECH 2014, pp. 180-183. Gabrovo: Unitech. 